\title{
AST, ALT and Albumin Level in Chronic Hepatitis B Patients with and without Complications of Cirrhosis and Hepatocellular Carcinoma
}

\author{
Viky Nafi'ah Rahma Maulidia ${ }^{1}$, Puspa Wardhani ${ }^{2}$, Bagus Setyoboedi $^{3}$ \\ ${ }^{1}$ Medical Student, Faculty of Medicine, Airlangga University, Surabaya, Indonesia \\ 2 Department of Clinical Pathology, Airlangga University/Dr. Soetomo Hospital in Surabaya, Indonesia. E-mail: puspa_pk@yahoo.co.id \\ ${ }^{3}$ Department of Pediatrics, Airlangga University/Dr. Soetomo Hospital Surabaya, Indonesia
}

\begin{abstract}
Complications of Chronic Hepatitis B (CHB) infection are liver cirrhosis and Hepatocellular Carcinoma (HCC). Aspartate Aminotransferase (AST), Alanine Aminotransferase (ALT), and albumin may be used as indicators of hepatocyte damage. This study aimed to determine differences between AST, ALT, and albumin in CHB patients without complications with CHB patients with cirrhosis and HCC complications. An analytical cross-sectional study was conducted in March-May 2019 on 62 CHB patients with or without cirrhosis or HCC complications using the total sampling method. AST and ALT were calculated using the Siemens Dimension device and International Federation of Clinical Chemistry (IFCC) method. The data were analyzed using independent samples T-test Albumin in $\mathrm{CHB}$ patients without complications was higher than $\mathrm{CHB}$ patients who had complications of liver cirrhosis $(p=0.002)$. The AST and ALT were not significantly different. Aspartate aminotransferase in $C H B$ with cirrhosis complications differed from CHB patients who had HCC complications $(p=0.015)$, however, not different in ALT and albumin. Aspartate aminotransferase, ALT, and albumin in $\mathrm{CHB}$ patients without complications were different from those with HCC complications. Albumin in $\mathrm{CHB}$ patients without complications was different from $\mathrm{CHB}$ patients with cirrhosis complications. Aspartate aminotransferase in $\mathrm{CHB}$ patients with cirrhosis complications was different from $\mathrm{CHB}$ patients who had HCC complications. As a result of these differences, an integrated approach to intervening liver damage may be needed to prevent the progression of the disease from becoming more severe.
\end{abstract}

Keywords: Aspartate aminotransferase, alanine aminotransferase, albumin, chronic hepatitis B, cirrhosis, hepatocellular carcinoma

\section{INTRODUCTION}

Hepatitis B Virus (HBV) infection is one of the significant health problems globally, especially Indonesia. ${ }^{1}$ Two billion people worldwide had been infected by hepatitis $B$ virus, and 240 million of them had Chronic Hepatitis B (CHB). ${ }^{2}$ Around the world, around 650 thousand people died every year due to $\mathrm{CHB}$ complications. Forty-five percent of $\mathrm{CHB}$ patients had HCC complications, while thirty percent of $\mathrm{CHB}$ patients had cirrhosis complications. ${ }^{3}$ Hepatocellular carcinoma is one of the leading causes of death in males, especially in Southeast Asia. In Asia, the rates of hepatocellular carcinoma and cirrhosis are low in the age range of 35-40 years but increase with age. ${ }^{4}$

The prevalence of chronic HBV infection varies geographically, from high prevalence (> 8\%), medium $(2-7 \%)$ to low $(<2 \%){ }^{5}$. Hepatitis B is endemic in developing regions with large populations such as Southeast Asia, China, sub-Saharan Africa, and the Amazon Valley, where at least $8 \%$ of the population are chronic carriers of HBV. In these areas, $70-95 \%$ of the population shows serological evidence of past or present from HBV infection. Most infections occur during infancy or childhood, most of which occur without symptoms. ${ }^{3}$

Indonesia is the second-highest endemicity country of hepatitis B in Southeast Asia after Myanmar in 2013. ${ }^{6}$ The data of Riskesdas 2017 said that $7.1 \%$ of Indonesia's population had hepatitis B. ${ }^{7}$ In 2013, around 2.8 million people in Indonesia were infected with hepatitis B and C, including the potential to become chronic and of the chronic 1.4 million had the possibility to suffer from hepatocellular carcinoma. ${ }^{6}$

Aspartate aminotransferase increase is more significant than $A L T$ in $C H B$, and albumin levels have decreased in $\mathrm{CHB}{ }^{8}{ }^{8}$ Liver function test is done to see the liver damage, especially liver enzyme tests. This enzyme is secreted by hepatocytes when cells are damaged. Aminotransferase is a specific indicator of hepatocyte necrosis. Aspartate aminotransferase is one of the enzymes used as indicators of liver tissue 
damage by the HBV. But, AST is less specific as a marker of liver damage. Its concentration also increases in the deterioration of other body tissues such as heart, kidney, striated muscles, and brain. Furthermore, ALT is more reliable and specific than AST to indicate liver damage because its increase is produced only by hepatocytes. ${ }^{9}$

Serum albumin levels will decrease if there is impaired function of albumin synthesis in hepatocytes, and chronic liver cell lesions occur. ${ }^{10,11}$ Low albumin serum levels found in patients with severe chronic liver disease such as cirrhosis are mostly caused by decreased synthesis of albumin. ${ }^{9}$

Clinicians must choose non-invasive indices in the patient's serum quickly and know their interpretations to prevent the progression of HBV infection to a more severe phase, death, and transmission to others around hepatitis B sufferers. Non-invasive tests used to assess the severity of liver disease are serum biochemical parameters, such as the ratio of AST to ALT, fibrosis score-4 (FIB-4), AST to platelet ratio index (APRI), spleen-platelet ratio, index of splenic-platelet index Forns, and the Hui index. ${ }^{12}$ Therefore, this study aimed to know the differences in AST, ALT, and albumin levels in CHB patients based on the presence or absence of cirrhosis complications and hepatocellular carcinoma complications in Dr. Soetomo Hospital, Surabaya.

\section{METHODS}

This study was a cross-sectional analytical study conducted in March-May 2019 after obtaining approval from the Dr. Soetomo Hospital Ethical Committee with the ethical clearance number of 1062/KEPK/III/2019. The samples were taken by a total sampling method. The data were obtained from medical records of $\mathrm{CHB}$ patients at Dr. Soetomo Hospital, Surabaya, in 2017-2018. The number of samples in this study was $62 \mathrm{CHB}$ patients with details of $25 \mathrm{CHB}$ patients without complications of liver cirrhosis and hepatocellular carcinoma, $25 \mathrm{CHB}$ patients with complications of liver cirrhosis, and 12 CHB patients with complications of hepatocellular carcinoma. Other diseases, which might affect AST, ALT, and albumin levels were excluded such as pancreatitis which increases blood levels of AST ALT, myocardial infarction, which increases AST levels, chronic kidney disease and renal impairment, which decreases albumin levels, bile duct obstruction, liver abscess and other liver diseases that affect blood levels of ALT. Aspartate aminotransferase and ALT levels in the blood were calculated using the Siemens
Dimension device and IFCC method. Albumin levels in the blood were calculated using the Siemens Dimension device and BCG (Bromocresol Green) method.

Data of AST, ALT, and albumin level in CHB patients with or without complications of cirrhosis or HCC were compared by independent samples T-test, with a significance level of $p<0.05$. Statistical analysis was done using SPSS 25.0 software.

\section{RESULTS AND DISCUSSION}

The samples were 62 patients in total with details of $25 \mathrm{CHB}$ patients without complications and 37 CHB patients with complications (25 patients with complications of liver cirrhosis and 12 patients with complications of hepatocellular carcinoma). Age 46.40 years was the average age of $\mathrm{CHB}$ patients without complications; age 51.16 years was the average age of $\mathrm{CHB}$ patients with cirrhosis complications, and age 48 was the average age of $\mathrm{CHB}$ patients with $\mathrm{HCC}$ complications). The average AST, ALT, and albumin levels of $\mathrm{CHB}$ patients without complications were $60.84 \mathrm{IU}, 42.08 \mathrm{IU}$, and $3.36 \mathrm{IU}$. The average AST, ALT, and albumin levels of CHB patients with cirrhosis complications were $125.96 \mathrm{IU}$, $88.32 \mathrm{IU}$, and $2.9 \mathrm{IU}$, respectively. The average AST, $A L T$, and albumin levels of CHB patients who had HCC complications were 390.16 IU, 114.16 IU, and 3.3 IU. The patients in all groups (CHB without complications, $\mathrm{CHB}$ with cirrhosis complications, and $\mathrm{CHB}$ with $\mathrm{HCC}$ complications) were mostly male (Table 1).

The prevalence of HBV-related liver disease was also observed to be higher in males than in females due to the mechanism of sex hormones of androgen and estrogen. ${ }^{13}$ The liver is considered a sexually dimorphic organ that expresses androgen receptors and estrogen receptors $\alpha .{ }^{14}$ The liver is responsive to sex hormones for differences found in gene expression patterns, immune responses, and xenobiotic metabolism between males and females. ${ }^{15}$ HBV $X$ protein $(\mathrm{HBX})$ increases hepatic androgen receptor activity by androgen-dependent mechanisms, strengthening sex differences in liver tissue in male patients infected with $\mathrm{HBV} .{ }^{16}$ Androgen Receptors (AR) increase HBV transcription, including all viral mRNA. Two Androgen-Responsive Elements (ARE) that are tightly bound to AR are found in the HBV genome nucleotide in enhancer I. These two ARE cause an increase in HBV mRNA levels caused by androgen receptors. Thus, $A R$ increases the transcription of $\mathrm{HBx}$. High $\mathrm{HBx}$ is directly proportional to the rise of ARE in the HBV genome. 
Thus, the ARE in the HBV genome causes a loop of reciprocal relations between androgen receptors and $\mathrm{HBx}$. ARE is the one responsible for the increment in HBV transcription regulation. Therefore, in male HBV patients, viral replication is more active, and the oncogenic potential is higher. ${ }^{13}$

Albumin serum levels in $\mathrm{CHB}$ patients without complications differed from $\mathrm{CHB}$ patients who experienced cirrhosis complications $(p=0.002)$, while not different in AST $(p=0.078)$ and ALT levels $(p=0.173)$ (Table 2). This finding was in line with other studies conducted in China, involving 201 CHB patients. The result was that patients in the $\mathrm{CHB}$ with liver cirrhosis group had lower albumin levels compared to the $\mathrm{CHB}$ without complications group with a $p$-value $<0.001 .^{17}$

Aspartate aminotransferase and ALT are enzymes that catalyze the transfer of $\alpha$-amino groups from aspartic and alanine to the $\alpha$-keto ketoglutaric acid groups to produce oxalic and pyruvic acids, which are important contributors to the citric acid cycle. ${ }^{18}$ Both enzymes require pyridoxal-5'-phosphate (vitamin B6) to carry out this reaction, although the effect of pyridoxal-5'-phosphate deficiency is higher on ALT activity than on AST. Both of these enzymes are highly concentrated in the liver. Aspartate aminotransferase is also diffuse in the heart, skeletal muscles, kidneys, brain, and red blood cells, and ALT has low concentrations in skeletal and kidney muscles. ${ }^{19}$ Therefore, an increase in ALT levels is more specific for liver damage. In the liver, ALT is localized only in the cellular cytoplasm, whereas AST is in the cytosol and mitochondria. ${ }^{20}$ The third zone of liver acini has a higher AST concentration, and the damage of this zone can cause more significant changes in AST levels. ${ }^{21}$ Patients with advanced liver cirrhosis always have hypoalbuminemia caused by decreased albumin synthesis by hepatocytes. Water and sodium retention affect the albumin content in the extracellular space. Other factors are likely to contribute to hypoalbuminemia, an increase in the transcapillary rate. ${ }^{22}$

Liver cirrhosis is divided into two stages, namely compensated cirrhosis and decompensated liver cirrhosis. In the asymptomatic phase of the disease, commonly referred to as compensated liver cirrhosis, patients may have a good quality of life and be undetected for several years. In the asymptomatic phase of the disease, commonly referred to as compensated liver cirrhosis, patients may have a good quality of life and be undetected for several years. Decompensated liver cirrhosis is characterized

Table 1. Characteristics of patients

\begin{tabular}{llll}
\hline Variables & CHB (n) & CHB with cirrhosis (n) & CHB with HCC (n) \\
\hline Number of patients & 25 & 25 & 12 \\
Age & $46.40 \pm 13.33$ & $51.16 \pm 9.74$ & $48.00 \pm 12.17$ \\
Gender & & & \\
Male patients & $21(84)$ & $21(84)$ & $8(66.7)$ \\
Female patients & $4(16)$ & $4(16)$ & $4(33.3)$ \\
AST & $60.84 \pm 49.85$ & $125.96 \pm 170.58$ & $390.16 \pm 309.23$ \\
ALT & $42.08 \pm 22.06$ & $88.32 \pm 163.37$ & $114.16 \pm 93.18$ \\
Albumin $^{\text {a }}$ & $3.36 \pm 0.49$ & $2.90 \pm 0.49$ & $3.03 \pm 0.33$ \\
\hline
\end{tabular}

Non-parametric variables are expressed as average \pm standard deviation

b Categorical variables are expressed as No. (\%)

Table 2. The differences between AST, ALT, and albumin in CHB patients without complications from those who experienced cirrhosis complication

\begin{tabular}{lccl}
\hline Variables & CHB without Complication & CHB with Cirrhosis & p-value \\
& $\bar{x} \pm$ SD & $\bar{x} \pm$ SD & \\
\hline AST & $60.84 \pm 49.85$ & $125.96 \pm 170.58$ & 0.078 \\
ALT & $42.08 \pm 22.06$ & $88.32 \pm 163.37$ & 0.173 \\
Albumin & $3.36 \pm 0.49$ & $2.90 \pm 0.49$ & 0.002 \\
\hline
\end{tabular}

Note: *Independent samples T-test

$\bar{x}=$ average

$\mathrm{SD}=$ Standard Deviation 
by clinical symptoms, including ascites, bleeding, encephalopathy, and jaundice. This disease usually develops faster towards death. ${ }^{23}$ Once decompensated liver cirrhosis has occurred, cirrhosis becomes a systemic disease, with multi-organ or organ system dysfunction. ${ }^{24}$ In compensated liver cirrhosis, AST and ALT levels tend to be normal. In decompensated liver cirrhosis, levels of AST and ALT in the blood tend to increase. ${ }^{25}$

In this study, there were no differences in levels of AST and ALT in research subjects suffering from $\mathrm{CHB}$ without complications, and $\mathrm{CHB}$ patients who experienced cirrhosis complications might be the cause of several factors, such as is the phase of $\mathrm{CHB}$ disease and prognosis of the disease.

Aspartate aminotransferase, ALT, and albumin levels in $\mathrm{CHB}$ patients without complications differed from $\mathrm{CHB}$ patients with $\mathrm{HCC}$ complications with $p$-values of $0.004,0.022$, and 0.020 , consecutively (Table 3). This finding was in line with other studies, which reported that AST and albumin levels in $\mathrm{CHB}$ patients without complications with $\mathrm{CHB}$ patients who experience HCC complications have significant differences with p-values of 0.043 and 0.001 , respectively. ${ }^{26}$

Hepatocellular carcinoma generally develops from chronic hepatitis or liver cirrhosis. In those two conditions, inflammation and regeneration of hepatocytes occur continuously. ${ }^{27}$ Chronic liver injury can cause permanent hepatocyte damage, resulting in compensation by cell proliferation. Because of this massive compensation, fibrosis and cirrhosis develop in the process of continuous liver remodeling. There are two main mechanisms in hepatocarcinogenesis, namely cirrhosis and the presence of DNA mutations that cause an imbalance of oncogenesis from cells, which ultimately leads to neoplastic cell development. ${ }^{28}$ Increased levels of the aminotransferase enzyme in hepatocellular carcinoma reflect damage to adjacent hepatocytes as a direct result of tumor growth or further damage to liver cells caused by disruption of blood supply or venous drainage. This may also be due to ongoing liver cell necrosis in those who have concomitant active cirrhosis or chronic active hepatitis. ${ }^{29}$

Tumor size affected albumin levels. In HCC patients, the higher the diameter of the tumor, the lower the albumin levels. Low albumin levels reflect damage to the liver parenchyma due to tumor growth. Decreased albumin levels are associated with a poor prognosis for hepatocellular carcinoma. ${ }^{30}$ The majority of samples of CHB patients with HCC complications had low albumin levels. In this study, albumin levels of study subjects who had CHB without complications with those who experienced HCC complications appeared to be different.

Low albumin levels or high levels of AST and ALT in patients with hepatocellular carcinoma were directly proportional to high HBV DNA levels. High levels of HBV DNA caused poor prognosis of hepatocellular carcinoma patients. ${ }^{31}$ In this study, AST and ALT levels of study subjects who had CHB without complications with those experiencing $\mathrm{HCC}$ complications appeared different according to statistical tests.

Aspartate aminotransferase serum levels in $\mathrm{CHB}$ with cirrhosis complications differed from $\mathrm{CHB}$ patients who had HCC complications $(p=0.015)$, while not different in ALT $(p=0.615)$ and albumin levels ( $p=0.371$ ) (Table 4). This finding was in line with other studies that reported that increased AST, ALT, and decreased albumin levels were associated with $\mathrm{CHB}$, with cirrhosis complications. ${ }^{32}$ Another study said that $90 \%$ of people with hepatocellular carcinoma had elevated AST levels and an abnormally reduced level of albumin in the blood. ${ }^{33}$ Elevated ALT levels were strongly associated with the incidence of hepatocellular carcinoma. ${ }^{34}$ In this study, there were differences in albumin levels between $\mathrm{CHB}$ with cirrhosis complications patients and $\mathrm{CHB}$ with hepatocellular carcinoma complications patients.

Table 3. The differences between AST, ALT, and albumin in CHB patients without complications from those who had hepatocellular carcinoma complication

\begin{tabular}{lcll}
\hline Variables & $\begin{array}{c}\text { CHB without Complication } \\
\bar{x} \pm \text { SD }\end{array}$ & $\begin{array}{c}\text { CHB with HCC } \\
\bar{x} \pm \text { SD }\end{array}$ & p-value \\
& $60.84 \pm 49.85$ & $390.16 \pm 309.23$ & 0.004 \\
AST & $42.08 \pm 22.06$ & $114.16 \pm 93.18$ & 0.022 \\
ALT & $3.36 \pm 0.49$ & $3.03 \pm 0.33$ & 0.020 \\
\hline Albumin & & & \\
\hline
\end{tabular}

Note: *Independent samples T-test

$\bar{x}=$ average

$\mathrm{SD}=$ Standard Deviation 
Table 4. The differences between AST, ALT, and albumin in CHB patients with cirrhosis complications from those who experienced hepatocellular carcinoma complications

\begin{tabular}{lcll}
\hline Variables & $\begin{array}{c}\text { CHB without Complication } \\
\bar{x} \pm \text { SD }\end{array}$ & $\begin{array}{c}\text { CHB with HCC } \\
\bar{x} \pm \text { SD }\end{array}$ & p-value \\
\hline AST & $125.96 \pm 170.58$ & $390.16 \pm 309.23$ & 0.015 \\
ALT & $88.32 \pm 163.37$ & $114.16 \pm 93.18$ & 0.615 \\
Albumin & $2.90 \pm 0.49$ & $3.03 \pm 0.33$ & 0.371 \\
\hline
\end{tabular}

Note: *Independent samples T-test $\quad \bar{x}=$ average $S D=$ Standard Deviation

\section{CONCLUSION AND SUGGESTION}

Aspartate aminotransferase, ALT, and albumin levels in CHB patients without complications were higher than those with hepatocellular carcinoma complications. Albumin levels in $\mathrm{CHB}$ patients without complications were more elevated than $\mathrm{CHB}$ patients with cirrhosis complications. Aspartate aminotransferase levels in $\mathrm{CHB}$ patients with cirrhosis complications were lower than $\mathrm{CHB}$ patients who had HCC complications. As a result of these differences, an integrated approach to intervening liver damage may be needed to prevent the disease's progression from becoming more severe.

\section{REFERENCES}

1. Perhimpunan Peneliti Hati Indonesia. Panduan tata laksana infeksi hepatitis B kronik. Jakarta, Perhimpunan Peneliti Hati Indonesia. 2006 [cited at April 15, 2018]. Available at http://www.pphi-online.org/

2. Khumaedi A, Gani R, Hasan I. Pencegahan transmisi vertikal hepatitis $B$ : Fokus pada penggunaan antivirus antenatal. Jurnal Penyakit Dalam Indonesia, 2017; 3(4): 225.

3. Alter M. Epidemiology of hepatitis B in Europe and worldwide. Journal of Hepatology, 2003; 39: 64-69.

4. World Health Organization. Guidelines for the prevention, care, and treatment of persons with chronic hepatitis B infection. Geneva, World Health Organization. 2015 [cited at April 15, 2018]. Available at https://www.who.int/hepatitis/publications/ hepatitis-b-guidelines/en/

5. Hou J, Liu Z, Gu, F. Epidemiology and prevention of hepatitis $B$ virus infection. International Journal of Medical Sciences, 2005; 2(1): 50-57.

6. Pusat Data dan Informasi Kementerian Kesehatan Republik Indonesia. InfoDATIN hepatitis. Jakarta Selatan, Pusat Data dan Informasi Kementerian Kesehatan Republik Indonesia. 2014 [cited at April 15, 2018]. Available at http://www.pusdatin.kemkes.go.id.

7. Kementerian Kesehatan Republik Indonesia. 150 ribu orang potensial mengalami hepatitis B kronis.
Biro Komunikasi dan Pelayanan Masyarakat, Kementerian Kesehatan Republik Indonesia. 2017 [cited at April 15, 2018]. Available www.depkes.go.id/article/view/17072800006/ 150-ribu-orang-potensial-alami-hepatitis-kronis.html

8. Betharina N, Hendriyono FX, Mashuri. Perbedaan hasil laboraturium penderita hepatitis B dan C kronis dengan derajat fibrosis hati. Berkala Kedokteran, 2017; 13(1): 41-46.

9. Thapa B, Walia A. Liver function tests and their interpretation. The Indian Journal of Pediatrics, 2007; 74(7): 663-671.

10. Sherlock S, Dooley J. Diseases of the liver and biliary system. $11^{\text {th }}$ Ed., United States of America, Blackwell Publishing, 2002; 32-34.

11. Dufour DR. Liver disease: Clinical chemistry and molecular diagnostics. $4^{\text {th }}$ Ed, Missouri, Elsevier, 2006; 1777-1827.

12. Asian Pacific Association for the study of liver. AsianPacific clinical practice guidelines on the management of hepatitis B. Hepatology International, 2016; 10(1): $1-98$.

13. Wang $\mathrm{SH}$, Yeh SH, Lin WH, Wang HY, Chen DS, Chen PJ. Identification of androgen response elements in the enhancer I of hepatitis B virus: A mechanism for sex disparity in chronic hepatitis B. Hepatology, 2009; 50(5): 1392-1402.

14. Ahlbory - Dieker DL, Stride BD, Leder G, Schkoldow J, Trölenberg $\mathrm{S}$, et al. DNA binding by estrogen receptor - alpha is essential for the transcriptional response to estrogen in the liver and the uterus. Mol. Endocrinol, 2009; 23(10): 1544-1555.

15. Waxman DJ, Holloway MG. Sex differences in the expression of hepatic drug metabolizing enzymes. Mol. Pharmacol, 2009; 76(2): 215-228.

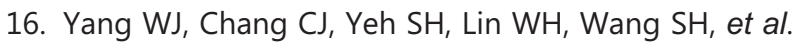
Hepatitis $B$ virus $X$ protein enhances the transcriptional activity of the androgen receptor through c - Src and glycogen synthase kinase - 3 beta kinase pathways. Hepatology, 2009; 49(5): 1515-1524.

17. Jia W, Qi X, Ji YY, Xun YH, Wang $H$, et al. Low serum hepatitis $B$ surface antigen level predicts compensated cirrhosis caused by chronic hepatitis Bin $\mathrm{HBeAg}$ positive patients in East China. Hepat Mon, 2015; 15(8): e30385.

18. Dufour DR, Lott JA, Nolte FS, Gretch DR, Koff RS, Seeff 
LB. Diagnosis and monitoring of hepatic injury. I. Performance characteristics of laboratory tests. Clinical Chemistry, 2000; 46(12): 2027-2049.

19. Wroblewski F. The clinical significance of alterations in transaminase activities of serum and other body fluids. Advances in Clinical Chemistry, 1958; 1: 313-351.

20. Rej R. Aminotransferases in disease. Clinical Laboratory Medicine, 1989; 9(4): 667-687.

21. Kamimoto Y, Horiuchi S, Tanase S, Morino Y. Plasma clearance of intravenously injected aspartate aminotransferase isozymes: Evidence for preferential uptake by sinusoidal liver cells. Hepatology, 1985; 5(3): 367-375.

22. Henricksen JH, Siemssen O, Krintel JJ, Malchow-Møller A, Bendtsen F, Ring-Larsen $\mathrm{H}$. Dynamics of albumin in plasma and ascites fluid in patients with cirrhosis. Journal of Hepatology, 2001; 16: 53-60.

23. D'Amico G. The clinical course of cirrhosis. Population-based studies and the need of personalized medicine. Journal of Hepatology, 2014; 60(2): 241-242.

24. Bernardi M, Moreau R, Angeli P, Schnabl B, Arroyo V. Mechanisms of decompensation and organ failure in cirrhosis: From peripheral arterial vasodilation to systemic inflammation hypothesis. Journal of Hepatology. 2015; 63(5): 1272-1284.

25. Elsing C, Harenberg S, Stremmel W, Hermann T. Serum levels of soluble Fas, nitric oxide, and cytokines in acute decompensated cirrhotic patients. World J Gastroenterol, 2007; 13(3): 421-425.

26. Chen S, Jia J, Gao Y, Li H, Fang M, et al. Clinical evaluation of hepatitis $B$ core-related antigen in chronic hepatitis $\mathrm{B}$ and hepatocellular carcinoma patients. International Journal of Clinical Chemistry,
2018; 486: 237-244.

27. Lemoine A, Saffroy R, Debuire B. Mechanisms of hepatocarcinogenesis. Atlas Genet Cytogenet Oncol Haematol, 2007; 11(1): 65-70.

28. Bertino G, Di Carlo I, Ardiri A, Calvagno GS, Demma S, et al. Systemic therapies in hepatocellular carcinoma: Present and future. Future Oncol, 2013; 9(10): 1533-1548.

29. Domingo EO, Lingao AL, Lao JY, et al. The significance of common laboratory tests in hepatocellular carcinoma. Philippine Journal of Internal Medicine, 2013; 51:1-3.

30. Carr B, Guerra V. Serum albumin levels in relation to tumor indis in hepatocellular carcinoma patients. The International Journal of Biological Markers, 2017; 32(4): 391-396.

31. Witjes C, Ijzermans J, van der Eijk A, Hansen B, Verhoef $C$, et al. Quantitative HBV-DNA and AST are strong predictors for survival after HCC detection in chronic HBV patiens. The Netherlands Journal of Medicine, 2011; 54: 508-513.

32. Merza M. Characteristics of chronic hepatitis B virus patients related liver cirrhosis in a tertiary care referral hospital, Duhok, Iraqi Kurdistan. Journal of Gastroenterology, Pancreatology \& Liver Disorders, 2017; 4(5): 1-5.

33. Lopez JB, Balasegaram $M$, Thambyrajah V, Timor J. the value of liver function test in hepatocellular carcinoma. The Malaysian Journal of Pathology, 1996; 18(2): 95-99.

34. Ishiguro $S$, Inoue $M$, Tanaka $Y$, Mizokami $M$, Iwasaki $M$, Tsugane S. Serum aminotransferase level and the risk of hepatocellular carcinoma: A population-based cohort study in Japan, Eur J Cancer Prev, 2009; 18(1): 26-31. 